\title{
Efektivitas Pelaksanaan Marketing Mix 9P Terhadap Kepuasan Pelayanan Klinik Rawat Jalan Rumah Sakit Jemursari Surabaya
}

\section{The Effectiveness of 9P Marketing Mix Implementation Towards the Service Satisfaction in the Outpatient Clinic of Jemursari Hospital Surabaya}

\author{
Satriya Wijaya ${ }^{1}$, Agus Aan Adriansyah ${ }^{2}$ \\ ${ }^{12}$ Universitas Nahdlatul Ulama Surabaya \\ Email : swijaya7@unusa.ac.id;aan.naufal87@unusa.ac.id
}

\begin{abstract}
ABSTRAK
Variabel Public relations dan Power sangat penting untuk mendukung terciptanya kepuasan konsumen yang berkelanjutan. Maka, pihak rumah sakit perlu memperhatikan kembali aspek bauran pemasaran demi menjaga kepuasan pasien dan menjaga respon baik pasien sebagai upaya rumah sakit dalam mempertahankan pelanggan lama untuk tetap memanfaatkan jasa pelayanan kesehatan. Penelitian ini termasuk jenis penelitian observasional sedangkan desain penelitian adalah penelitian cross sectional. Besar sampel penelitian ini sejumlah 87 responden yang ditentukan dengan menggunakan rumus yang digunakan untuk penelitian yang bersifat survei atau observasional. Variabel yang diamati adalah efektivitas pelaksanaan Marketing Mix (9P) mulai variabel Product, Price, Place, Promotion, People, Process, Physical Evidence, Public relations, Power terhadap kepuasan pelayanan. Analisis data dilakukan dengan tabulasi silang dan analisis pareto 80/20. Hasil penelitian menunjukkan Marketing mix product, place, promotion, people, process, physical evidence, public relation, power belum efektif karena pasien yang sangat puas masih dibawah $80 \%$. Hanya Marketing Mix price responden yang cukup puas $100 \%$ dan ini bisa dikatakan cukup efektif karena melebihi 80\% sedangkan Marketing Mix 9P dikatakan belum efektif karena walaupun sebagian responden mengatakan sudah cukup optimal namun pasien yang cukup puas masih dibawah 80\%.
\end{abstract}

Kata Kunci: Efektivitas Marketing Mix 9P, Marketing mix 9P, Marketing mix 9P terhadap kepuasan pelayanan

\footnotetext{
ABSTRACT

Variables including Public Relation and Power are highly significant in supporting the establishment of a sustainable customer satisfaction. Thus, hospitals need to put their attention upon the marketing mix aspect to maintain the satisfaction and the good response of the patients as the efforts from the hopitals to retain the old customers to keep utilizing their health services. This research is an observational research by using a cross-sectional study as its design. Samples of this research are 87 respondents selected through a formula used for survey or observational research. The observed variables are the effectiveness of the Marketing Mix (9P), including items such as Product, Price, Place, Promotion, People, Process, Physical Evidence, Public Relations, and Power, toward the service satisfaction. Data analysis is performed through a cross tabulation and pareto analysis of 80/20. The results of this research show that the marketing mix variables such as products, places, promotions, people, processes, physical evidences, public relations, and power are not effective enough, since very-satisfied patients are still below 80\%. It's only respondents of Marketing Mix variable, price, that appears at $100 \%$ in satisfaction, thus can be entitled as 'quite effective', since it exceeds $80 \%$. Whereas, the 9P Marketing Mix is said to be ineffective due to the reason that although some respondents claim it as 'quite optimal', yet satisfied patients are still below $80 \%$.
}

Keywords: The Effectiveness Of 9P Marketing Mix, 9P Marketing Mix, 9P Marketing Mix Towards The Service Satisfaction 
Jurnal Manajemen Kesehatan Yayasan RS.Dr.Soetomo Vol.6 No.1 April 2020 :

\section{PENDAHULUAN}

Rumah Sakit sebagai institusi penyelenggara pelayanan kesehatan yang kompleks, padat pakar, dan padat modal harus memiliki kemampuan untuk menarik dan mempertahankan pelanggan baru yang tidak hanya berasal dari produk atau pelayanan itu sendiri, tetapi juga berkaitan dengan bagaimana organisasi tersebut melayani pelanggan lama dan reputasi yang diciptakan oleh rumah sakit, baik didalam maupun diluar rumah sakit. Rumah sakit harus memiliki strategi dan program pemasaran yang tepat untuk dapat mempertahankan respon baik dari para pelanggan (pasien) lama karena mencari pelanggan baru lebih sulit dan memerlukan biaya yang lebih mahal bila dibandingkan dengan mempertahankan pelanggan lama.

Di era Masyarakat Ekonomi Asean (MEA) ini, kepuasan pelanggan jasa kesehatan salah satunya disebabkan oleh efektivitas pelaksanaan bauran pemasaran. Bauran pemasaran yang bisa dikatakan paling terkini untuk saat ini yaitu bauran pemasaran 9P. Di Indonesia bauran pemasaran 9P masih jarang diterapkan oleh provider pelayanan jasa khususnya jasa kesehatan karena masih berkutat pada 4P sampai dengan 7P. Salah satu organisasi penyedia jasa kesehatan di Indonesia yang telah melaksanakan bauran pemasaran 9P yaitu Rumah Sakit Islam Jemursari Surabaya. Namun, dari 9 komponen ini implementasinya masih belum optimal terutama untuk Public relations dan Power. Variabel Public relations dan Power sangat penting untuk mendukung terciptanya kepuasan konsumen yang berkelanjutan.

Variabel Public relations dan Power sangat penting untuk mendukung terciptanya kepuasan konsumen yang berkelanjutan. Tujuan utama dari public relation adalah memengaruhi perilaku orang secara individu maupun kelompok saat saling berhubungan, melalui dialog dengan semua golongan, ketika persepsi, sikap dan opininya penting terhadap suatu kesuksesan sebuah perusahaan (Davis \& Dasar, 2012). Power adalah upaya yang dilakukan dalam rangka memanfaatkan peluang yang timbul dari adanya peraturan mengenai usaha yang dilakukan atau bisa juga diartikan sebagai mengenali, membina hubungan dengan pihak yang memiliki pengaruh terhadap pasar. Berdasarkan pengambilan data awal 
Satriya Wijaya, Agus Aan Adriansyah : The Effectiveness of 9P Marketing Mix ...

wawancara dengan pihak stakeholder bagian marketing dan humas RSI Jemursari Surabaya, mengatakan bahwa sejauh ini konsep bauran pemasaran yang telah dilakukan oleh Rumah Sakit Islam Jemursari Surabaya telah mengimplementasikan marketing mix $9 P$ namun pelaksanaannya dirasa masih belum optimal terutama untuk Public relations dan Power.

Selain itu, menurut penuturan Kabid Marketing dan Humas, RSI Jemursari Surabaya adalah Rumah Sakit Pendidikan tipe B dengan pasien 70\% adalah pasien BPJS. Sesuai aturan dari BPJS, RS tipe B adalah RS rujukan dari RS tipe C atau Klinik Pratama ketika pasien memerlukan penanganan dokter spesialis. Jadi melihat aturan tersebut pada kenyataannya angka kunjungan di Poli Spesialis lebih banyak dibanding poli umum. Selain itu poli umum RSI Jemursari lebih banyak difungsikan pelayanan pegawai RSI Jemursari dan pasien asuransi yang membutuhkan rujukan dari dokter umum ke poli spesialis.

Berdasar data jumlah kunjungan pasien rawat jalan Rumah Sakit Islam Jemursari Surabaya selama periode tahun 2016 sampai dengan tahun 2018 didapatkan jumlah kunjungan untuk pelayanan poli umum masih jauh lebih sedikit bila dibandingkan pelayanan poli jantung, poli penyakit dalam, poli anak dan poli kandungan. Melihat kondisi ini peneliti tertarik memilih mengambil responden pasien poli umum sebagai responden penelitian. Berdasarkan informasi data tersebut maka tujuan penelitian ini yaitu untuk menganalisis efektivitas pelaksanaan Marketing Mix (9P) terhadap kepuasan pelayanan klinik rawat jalan Rumah Sakit (Studi di Poli Umum Rumah Sakit Islam Jemursari Surabaya).

\section{METODE}

Penelitian ini termasuk jenis penelitian observasional. Sedangkan disain penelitian, penelitian ini termasuk dalam penelitian cross sectional karena variabel penelitian diukur secara simultan atau dalam waktu yang bersamaan sehingga diperoleh gambaran keadaan pada waktu tersebut (Notoatmodjo, 2010). Penentuan besar sampel pada penelitian ini menggunakan data rata-rata kunjungan pasien per hari (kunjungan pasien = 36 orang/hari). dikalikan 24 hari (4 minggu) pada layanan rawat jalan di Poli Umum yaitu sebesar 864 orang. Kemudian 
ditentukan dengan menggunakan rumus yang digunakan untuk penelitian yang bersifat survei atau observasional. Setelah dihitung dengan rumus, besar sampel ditentukan sejumlah 87 responden. Cara pengambilan sampel responden dilakukan dengan cara diambil setiap hari selama 12 hari dengan teknik random sampling berdasar nomor urut panggilan pasien Poli Umum yang ditentukan dengan mengundi nomor urut pasien, nomor yang keluar diambil sebagai sampel responden.

Variabel yang diukur dan diamati dalam penelitian adalah pelaksanaan Marketing Mix (9P) mulai variabel Product, Price, Place, Promotion, People, Process, Physical Evidence, Public relations, Power dan kepuasan pelayanan. Pengolahan data dilakukan secara bertahap dengan teknik editing, skoring, coding, dan tabulasi. Untuk analisis data, dilakukan dengan tabulasi silang yang kemudian dianalisis menggunakan hukum pareto 80/20. Menurut (Haughey, 2010) analisis pareto adalah teknik statistik dalam pengambilan keputusan yang digunakan untuk pemilihan sejumlah tugas yang menghasilkan efek keseluruhan yang signifikan. Prinsip Pareto (juga dikenal sebagai aturan 80/20) ini bahwa dengan melakukan 20\% dari pekerjaan anda dapat menghasilkan 80\% dari keuntungan melakukan seluruh pekerjaan kemudian dalam hal peningkatan kualitas, sebagian besar masalah (80\%) yang dihasilkan oleh penyebab kunci (20\%).

\section{HASIL}

Berdasarkan hasil penelitian bahwa hampir separuh (34,5\%) responden bekerja sebagai karyawan swasta dan ibu rumah tangga, hampir separuh $(26,4 \%)$ responden berumur 26-35 tahun, dan sebagian besar (63,2\%) responden berpendidikan SMA/SMK. Responden yang mengatakan product sesuai harapan pasien (58,8\%) merasa sangat puas akan pelayanan Poli Umum RSI Jemursari Surabaya. Analisis secara hukum Pareto 80/20, dapat dikatakan bahwa walaupun product sudah sesuai harapan pasien namun belum bisa dikatakan efektif dikarenakan pasien yang sangat puas belum mencapai 80\%. Responden yang mempersepsikan price kurang memenuhi harapan pasien (100\%) merasa cukup puas akan pelayanan Poli Umum RSI Jemursari Surabaya. Apabila dianalisis 
Satriya Wijaya, Agus Aan Adriansyah : The Effectiveness of 9P Marketing Mix ...

secara Pareto 80/20, walaupun price kurang memenuhi harapan pasien, tingkat kepuasan pelayanan pasien yang cukup puas mencapai 100\%. Hal ini menginformasikan bahwa tingkat efektivitas pelaksanaan marketing mix (Price) terhadap kepuasan pelayanan dapat dikatakan efektif.

Responden yang mempersepsikan place sudah sesuai harapan pasien (57,1\%) merasa sangat puas akan pelayanan Poli Umum RSI Jemursari Surabaya. Dan apabila dianalisis secara Pareto 80/20 belum bisa dikatakan efektif dikarenakan place yang sudah sesuai harapan pasien hanya dapat menjadikan pasien sangat puas sebesar 57,1\% (dibawah 80\%). Responden yang mengatakan promotion sudah sesuai harapan pasien $(68,2 \%)$ merasa sangat puas akan pelayanan Poli Umum RSI Jemursari Surabaya. Dan apabila dianalisis secara hukum Pareto 80/20 belum bisa dikatakan efektif dikarenakan promotion yang sudah sesuai harapan pasien hanya dapat menjadikan pasien sangat puas sebesar 68,2\% (dibawah 80\%). Responden yang mengatakan people cukup memenuhi harapan pasien (62,2\%) merasa cukup puas akan pelayanan Poli Umum RSI Jemursari. Dan apabila dianalisis secara Pareto 80/20 belum bisa dikatakan efektif dikarenakan people yang telah cukup memenuhi harapan pasien hanya dapat menjadikan pasien cukup puas sebesar 62,2\% (dibawah 80\%).

Responden yang mempersepsikan process sudah sesuai harapan pasien (63,6\%) merasa sangat puas akan pelayanan Poli Umum RSI Jemursari Surabaya. Dan apabila dianalisis secara Pareto 80/20 belum bisa dikatakan efektif dikarenakan process yang sudah sesuai harapan pasien hanya dapat menjadikan pasien sangat puas sebesar 63,6\% (dibawah 80\%). Responden yang mempersepsikan physical evidence cukup memenuhi harapan pasien (55,6\%) merasa cukup puas akan pelayanan Poli Umum RSI Jemursari Surabaya. Dan apabila dianalisis secara Pareto 80/20 belum bisa dikatakan efektif dikarenakan physical evidence cukup memenuhi harapan pasien hanya dapat menjadikan pasien cukup puas sebesar 55,6\% (dibawah 80\%).

Responden yang mengatakan public relation sudah sesuai harapan pasien (64,7\%) merasa sangat puas akan pelayanan Poli Umum RSI Jemursari Surabaya. Dan apabila dianalisis secara Pareto $80 / 20$ belum bisa dikatakan efektif 
dikarenakan public relation yang sudah sesuai harapan pasien hanya dapat menjadikan pasien sangat puas sebesar 64,7\% (dibawah 80\%). Responden yang mengatakan power cukup memenuhi harapan pasien (50,7\%) merasa sangat puas akan pelayanan Poli Umum RSI Jemursari Surabaya. Dan apabila dianalisis secara Pareto 80/20 dapat dikatakan belum efektif dikarenakan power yang cukup memenuhi harapan pasien hanya dapat menjadikan pasien sangat puas sebesar 50,7\% (dibawah 80\%). Responden yang mengatakan marketing mix 9P sudah cukup optimal $(65,4 \%)$ merasa cukup puas akan pelayanan di Poli Umum RSI Jemursari Surabaya. Dan apabila dianalisis secara Pareto 80/20 belum bisa dikatakan efektif dikarenakan marketing mix 9P yang sudah cukup optimal hanya dapat menjadikan pasien cukup puas hanya sebesar 65,4\% (dibawah 80\%). Responden yang mengatakan product sesuai harapan pasien, sebagian besar merasa sangat puas. Namun, dari hasil analisis pareto 80/20 walaupun product sudah sesuai harapan pasien namun belum bisa dikatakan efektif dikarenakan pasien yang sangat puas belum mencapai $80 \%$.

Hal ini sesuai yang dijelaskan oleh Kotler \& Amstrong (2001) bahwa marketing mix product merupakan salah satu faktor penting untuk mewujudkan kepuasan pelanggan dan merupakan alasan yang mendasari seseorang untuk melakukan suatu tindakan. Oleh karena itu bila melihat dari hasil penelitian bahwa responden yang mengatakan product sesuai harapan pasien, sebagian besar telah merasa sangat puas.

Produk adalah apa yang dapat ditawarkan didalam pasar untuk dipertahankan, dimiliki, digunakan atau dikonsumsi sehingga dapat memuaskan keinginan atau kebutuhan termasuk didalamnya adalah objek fisik, jasa, orang, tempat organisasi dan gagasan”. Sehingga dapat disimpulkan bahwa yang dimaksud produk adalah suatu yang berwujud maupun sesuatu yang tidak berwujud yang lazim disebut jasa, contohnya : kualitas, penampilan, tambahan gaya, merk, pengepakan, ukuran, pelayanan, garansi (Kotler et al., 2012)

Hasil penelitian menunjukkan bahwa responden yang mempersepsikan price kurang memenuhi harapan pasien, semua responden merasa cukup puas akan pelayanan Poli Umum RSI Jemursari Surabaya. Dan dari hasil analisis Pareto 
Satriya Wijaya, Agus Aan Adriansyah : The Effectiveness of 9P Marketing Mix ...

80/20, walaupun price kurang memenuhi harapan pasien, tingkat kepuasan pelayanan pasien yang cukup puas mencapai 100\%. Hal ini menginformasikan bahwa tingkat efektivitas pelaksanaan marketing mix (Price) terhadap kepuasan pelayanan dapat dikatakan efektif. Hal ini sesuai yang disampaikan oleh (Monroe, 2011) yang menyatakan bahwa harga merupakan pengorbanan ekonomis yang dilakukan pelanggan untuk memperoleh produk atau jasa. Selain itu harga merupakan salah satu faktor penting konsumen dalam mengambil keputusan untuk melakukan transaksi atau tidak.

Responden yang mempersepsikan place sudah sesuai harapan pasien sebagian besar merasa sangat puas akan pelayanan Poli Umum RSI Jemursari Surabaya. Dan dari hasil analisis Pareto 80/20 belum bisa dikatakan efektif dikarenakan place yang sudah sesuai harapan pasien hanya dapat menjadikan pasien sangat puas sebesar 57,1\% (dibawah 80\%). Distribusi (place), yakni memilih dan mengelola saluran perdagangan yang dipakai untuk menyalurkan produk atau jasa dan juga untuk melayani pasar sasaran, serta mengembangkan sistem distribusi untuk pengiriman dan perniagaan produk secara fisik. Keputusan penentuan lokasi dan saluran yang digunakan untuk memberikan jasa kepada pelanggan melibatkan pemikiran tentang bagaimana mengirimkan atau menyampaikan jasa kepada pelanggan dan dimana hal tersebut akan dilakukan. Ini harus dipertimbangkan karena dalam bidang jasa sering kali tidak dapat ditentukan tempat dimana diproduksi dan dikonsumsi pada saat bersamaan.

Responden responden yang mengatakan promotion sudah sesuai harapan pasien (68,2\%) merasa sangat puas akan pelayanan Poli Umum RSI Jemursari Surabaya. Dan apabila dianalisis secara hukum Pareto 80/20 belum bisa dikatakan efektif dikarenakan promotion yang sudah sesuai harapan pasien hanya dapat menjadikan pasien sangat puas sebesar 68,2\% (dibawah 80\%). Hal ini sesuai dengan yang dikatakan oleh (Kotler \& Armstrong, 2018) bahwa promosi mengacu pada kegiatan yang mengkomunikasikan keunggulan produk dan meyakinkan target pelanggan untuk membelinya sehingga secara tidak langsung akan berdampak pada tingkat kepuasan pelayanan. 
Jurnal Manajemen Kesehatan Yayasan RS.Dr.Soetomo Vol.6 No.1 April 2020 :

Responden yang mengatakan people cukup memenuhi harapan pasien (62,2\%) merasa cukup puas akan pelayanan Poli Umum RSI Jemursari. Dan apabila dianalisis secara Pareto 80/20 belum bisa dikatakan efektif dikarenakan people yang telah cukup memenuhi harapan pasien hanya dapat menjadikan pasien cukup puas sebesar 62,2\% (dibawah 80\%). Orang (People), adalah semua pelaku yang memainkan peranan penting dalam penyajian jasa sehingga dapat mempengaruhi persepsi pembeli. Elemen dari orang adalah pegawai perusahaan, konsumen, dan konsumen lain. Semua sikap dan tindakan karyawan, cara berpakaian karyawan dan penampilan karyawan memiliki pengaruh terhadap keberhasilan penyampaian jasa. Orang merupakan unsur vital dalam pemasaran. Setiap organisasi jasa harus jelas menentukan apa yang diharapkan dari setiap karyawan dalam interaksinya dengan pelanggan. Apakah karyawan bersikap baik terhadap pelanggan, ramah, responsif dan mampu melayani pelanggan dengan baik.

Responden yang mempersepsikan process sudah sesuai harapan pasien (63,6\%) merasa sangat puas akan pelayanan Poli Umum RSI Jemursari Surabaya. Dan apabila dianalisis secara Pareto 80/20 belum bisa dikatakan efektif dikarenakan process yang sudah sesuai harapan pasien hanya dapat menjadikan pasien sangat puas sebesar 63,6\% (dibawah 80\%). Proses (Process), adalah semua prosedur aktual, mekanisme, dan aliran aktivitas yang digunakan untuk menyampaikan jasa. Elemen proses ini memiliki arti sesuatu untuk menyampaikan jasa. Proses dalam jasa merupakan faktor utama dalam bauran pemasaran jasa seperti pelanggan jasa akan senang merasakan sistem penyerahan jasa sebagai bagian jasa itu sendiri. Proses yang dimaksud adalah kecepatan penanganan maupun kelancaran distribusi hingga ke tangan konsumen akhir. Seluruh aktifitas kerja adalah proses, proses melibatkan prosedur - prosedur, tugas - tugas, jadwal, mekanisme, aktifitas dan rutinitas dengan apa produk (barang atau jasa) disalurkan ke pelanggan.

Responden yang mempersepsikan physical evidence cukup memenuhi harapan pasien $(55,6 \%)$ merasa cukup puas akan pelayanan Poli Umum RSI Jemursari Surabaya. Dan apabila dianalisis secara Pareto 80/20 belum bisa 
Satriya Wijaya, Agus Aan Adriansyah : The Effectiveness of 9P Marketing Mix ...

dikatakan efektif dikarenakan physical evidence cukup memenuhi harapan pasien hanya dapat menjadikan pasien cukup puas sebesar 55,6\% (dibawah 80\%). Sarana fisik (Physical Evidence), merupakan segala sesuatu bukti fisik perusahaan dalam mendukung produk atau jasa yang di tawarkan atau hal nyata yang turut mempengaruhi keputusan konsumen untuk membeli dan menggunakan produk atau jasa yang ditawarkan. Unsur yang termasuk dalam sarana fisik antara lain lingkungan atau bangunan fisik, peralatan, perlengkapan, logo, warna gedung, kendaraan, peralatan, seragam karyawan dan barang-barang lainnya.

Responden yang mempersepsikan public relation sudah sesuai harapan pasien $(64,7 \%)$ merasa sangat puas akan pelayanan Poli Umum RSI Jemursari Surabaya. Hasil analisis secara Pareto 80/20 belum bisa dikatakan efektif dikarenakan public relation yang sudah sesuai harapan pasien hanya dapat menjadikan pasien sangat puas sebesar 64,7\% (dibawah 80\%). Public Relation merupakan seni menciptakan pengertian publik yang lebih baik sehingga dapat memperdalam kepercayaan publik terhadap suatu individu/Organisasi. Tujuan utama dari public relation adalah mempengaruhi perilaku orang secara individu maupun kelompok saat saling berhubungan, melalui dialog dengan semua golongan, dimana persepsi, sikap dan opininya penting terhadap suatu kesuksesan sebuah perusahaan.

Responden yang mempersepsikan power cukup memenuhi harapan pasien (50,7\%) merasa sangat puas akan pelayanan Poli Umum RSI Jemursari Surabaya. Dan apabila dianalisis secara Pareto 80/20 dapat dikatakan belum efektif dikarenakan power yang cukup memenuhi harapan pasien hanya dapat menjadikan pasien sangat puas sebesar 50,7\% (dibawah 80\%). Power adalah upaya-upaya yang dilakukan dalam rangka memanfaatkan peluang yang timbul dari adanya peraturan mengenai usaha yang dilakukan atau bisa juga diartikan sebagai mengenali, membina hubungan dengan pihak-pihak yang memiliki pengaruh terhadap pasar. Power disini meliputi kekuatan merk atau barang itu sendiri yang tercipta di benak konsumen dan mampu membuat produknya menjadi kuat di pasaran. 
Responden yang mempersepsikan bahwa responden yang mengatakan marketing mix 9P sudah cukup optimal $(65,4 \%)$ merasa cukup puas akan pelayanan di Poli Umum RSI Jemursari Surabaya apabila dianalisis secara Pareto 80/20 belum bisa dikatakan efektif dikarenakan marketing mix 9P yang sudah cukup optimal hanya dapat menjadikan pasien cukup puas hanya sebesar 65,4\% (dibawah 80\%). Marketing mix 9P merupakan suatu strategi pemasaran yang menggabungkan beberapa elemen (9 elemen) di dalam marketing mix itu sendiri yang dilakukan secara terpadu. Elemen-elemen di dalam Marketing mix 9P terdiri dari Product, Price, Place, Promotion, People, Process, Physical Evidence, Public Relation, Power yang teridentifikasi berkaitan erat dengan kepuasan pelayanan. Responden yang mengatakan product sesuai harapan pasien, sebagian besar merasa sangat puas. Namun, dari hasil analisis pareto 80/20 walaupun product sudah sesuai harapan pasien namun belum bisa dikatakan efektif dikarenakan pasien yang sangat puas belum mencapai 80\%. Hal ini sesuai yang disampaikan oleh Kotler \& Amstrong (2001) bahwa marketing mix product merupakan salah satu faktor penting untuk mewujudkan kepuasan pelanggan dan merupakan alasan yang mendasari seseorang untuk melakukan tindakan. Oleh karena itu bila melihat dari hasil penelitian bahwa responden yang mengatakan product sesuai harapan pasien, sebagian besar telah merasa sangat puas.

Produk adalah apa yang dapat ditawarkan didalam pasar untuk dipertahankan, dimiliki, digunakan atau dikonsumsi sehingga dapat memuaskan keinginan atau kebutuhan termasuk didalamnya adalah objek fisik, jasa, orang, tempat organisasi dan gagasan”. Sehingga dapat disimpulkan bahwa yang dimaksud produk adalah suatu yang berwujud maupun sesuatu yang tidak berwujud yang lazim disebut jasa, contohnya : kualitas, penampilan, tambahan gaya, merk, pengepakan, ukuran, pelayanan, garansi (Kotler et al., 2012)

Berdasarkan hasil penelitian menunjukkan bahwa responden yang mempersepsikan price kurang memenuhi harapan pasien, semua responden merasa cukup puas akan pelayanan Poli Umum RSI Jemursari Surabaya. Hasil analisis Pareto 80/20, walaupun price kurang memenuhi harapan pasien, tingkat kepuasan pelayanan pasien yang cukup puas mencapai 100\%. Hal ini 
Satriya Wijaya, Agus Aan Adriansyah : The Effectiveness of 9P Marketing Mix ...

menginformasikan bahwa tingkat efektivitas pelaksanaan marketing mix (Price) terhadap kepuasan pelayanan dapat dikatakan efektif.

Hal ini sesuai yang disampaikan oleh (Monroe, 2011) yang menyatakan bahwa harga merupakan pengorbanan ekonomis yang dilakukan pelanggan untuk memperoleh produk atau jasa. Selain itu harga merupakan salah satu faktor penting konsumen dalam mengambil keputusan untuk melakukan transaksi atau tidak (Widayati, 2012). Responden yang mempersepsikan place sudah sesuai harapan pasien sebagian besar merasa sangat puas akan pelayanan Poli Umum RSI Jemursari Surabaya. Hasil analisis Pareto 80/20 belum bisa dikatakan efektif dikarenakan place yang sudah sesuai harapan pasien hanya dapat menjadikan pasien sangat puas sebesar $57,1 \%$ (dibawah $80 \%$ ).

Distribusi (place), yakni memilih dan mengelola saluran perdagangan yang dipakai untuk menyalurkan produk atau jasa dan juga untuk melayani pasar sasaran, serta mengembangkan sistem distribusi untuk pengiriman dan perniagaan produk secara fisik. Keputusan penentuan lokasi dan saluran yang digunakan untuk memberikan jasa kepada pelanggan melibatkan pemikiran tentang bagaimana cara mengirimkan atau menyampaikan jasa kepada pelanggan dan dimana hal tersebut akan dilakukan. Ini harus dipertimbangkan karena dalam bidang jasa sering kali tidak dapat ditentukan tempat dimana akan diproduksi dan dikonsumsi pada saat bersamaan.

Berdasarkan hasil penelitian menunjukkan bahwa responden yang mengatakan promotion sudah sesuai harapan pasien (68,2\%) merasa sangat puas akan pelayanan Poli Umum RSI Jemursari Surabaya. Hasil analisis secara hukum Pareto 80/20 belum bisa dikatakan efektif dikarenakan promotion yang sudah sesuai harapan pasien hanya dapat menjadikan pasien sangat puas sebesar 68,2\% (dibawah 80\%). Hal ini sesuai dengan yang dikatakan oleh (Kotler \& Armstrong, 2018) bahwa promosi mengacu pada kegiatan yang mengkomunikasikan keunggulan produk dan meyakinkan target pelanggan untuk membelinya sehingga secara tidak langsung akan berdampak pada tingkat kepuasan pelayanan.

Berdasarkan hasil penelitian menunjukkan bahwa responden yang mengatakan people cukup memenuhi harapan pasien (62,2\%) merasa cukup puas 
Jurnal Manajemen Kesehatan Yayasan RS.Dr.Soetomo Vol.6 No.1 April 2020 :

akan pelayanan Poli Umum RSI Jemursari. Hasil analisis secara Pareto 80/20 belum bisa dikatakan efektif dikarenakan people yang telah cukup memenuhi harapan pasien hanya dapat menjadikan pasien cukup puas sebesar 62,2\% (dibawah 80\%).

Orang (People), adalah semua pelaku yang memainkan peranan penting dalam penyajian jasa sehingga dapat mempengaruhi persepsi pembeli. Elemen dari orang adalah pegawai perusahaan, konsumen, dan konsumen lain. Semua sikap dan tindakan karyawan, cara berpakaian karyawan dan penampilan karyawan memiliki pengaruh terhadap keberhasilan penyampaian jasa. Orang merupakan unsur vital dalam pemasaran. Setiap organisasi jasa harus jelas menentukan apa yang diharapkan dari setiap karyawan dalam interaksinya dengan pelanggan. Apakah karyawan bersikap baik terhadap pelanggan, ramah, responsif dan mampu melayani pelanggan dengan baik (Griffin, 2005). Responden yang mempersepsikan process sudah sesuai harapan pasien $(63,6 \%)$ merasa sangat puas akan pelayanan Poli Umum RSI Jemursari Surabaya. Hasil analisis secara Pareto 80/20 belum bisa dikatakan efektif dikarenakan process yang sudah sesuai harapan pasien hanya dapat menjadikan pasien sangat puas sebesar 63,6\% (dibawah 80\%).

Proses (Process), adalah semua prosedur aktual, mekanisme, dan aliran aktivitas yang digunakan untuk menyampaikan jasa. Elemen proses ini memiliki arti sesuatu untuk menyampaikan jasa. Proses dalam jasa merupakan faktor utama dalam bauran pemasaran jasa seperti pelanggan jasa akan senang merasakan sistem penyerahan jasa sebagai bagian jasa itu sendiri. Proses yang dimaksud adalah kecepatan penanganan maupun kelancaran distribusi hingga ke tangan konsumen akhir. Seluruh aktifitas kerja adalah proses, proses melibatkan prosedur - prosedur, tugas - tugas, jadwal, mekanisme, aktifitas dan rutinitas dengan apa produk (barang atau jasa) disalurkan ke pelanggan. Hal ini sesuai dengan yang disampaikan (Sukotjo \& Radix, 2010) yang mengatakan bahwa pada proses pelayanan jasa yang dilakukan dengan sangat baik, akan berdampak pada peningkatan persepsi kepuasan pelanggan akan pelayanan yang diberikan. 
Satriya Wijaya, Agus Aan Adriansyah : The Effectiveness of 9P Marketing Mix ...

Responden yang mempersepsikan physical evidence cukup memenuhi harapan pasien (55,6\%) merasa cukup puas akan pelayanan Poli Umum RSI Jemursari Surabaya. Hasil analisis secara Pareto 80/20 belum bisa dikatakan efektif dikarenakan physical evidence cukup memenuhi harapan pasien hanya dapat menjadikan pasien cukup puas sebesar 55,6\% (dibawah 80\%). Sarana fisik (Physical Evidence), merupakan segala sesuatu bukti fisik perusahaan dalam mendukung produk atau jasa yang di tawarkan atau hal nyata yang turut mempengaruhi keputusan konsumen untuk membeli dan menggunakan produk atau jasa yang ditawarkan. Unsur yang termasuk dalam sarana fisik antara lain lingkungan atau bangunan fisik, peralatan, perlengkapan, logo, warna gedung, kendaraan, peralatan, seragam karyawan dan barang-barang lainnya.

Berdasarkan hasil penelitian menunjukkan bahwa responden yang mempersepsikan public relation sudah sesuai harapan pasien $(64,7 \%)$ merasa sangat puas akan pelayanan Poli Umum RSI Jemursari Surabaya. Hasil analisis secara Pareto 80/20 belum bisa dikatakan efektif dikarenakan public relation yang sudah sesuai harapan pasien hanya dapat menjadikan pasien sangat puas sebesar 64,7\% (dibawah 80\%). Public Relation merupakan seni menciptakan pengertian publik yang lebih baik sehingga dapat memperdalam kepercayaan publik terhadap suatu individu/Organisasi. Tujuan utama dari public relation adalah mempengaruhi perilaku orang secara individu maupun kelompok saat saling berhubungan, melalui dialog dengan semua golongan, dimana persepsi, sikap dan opininya penting terhadap suatu kesuksesan sebuah perusahaan.

Responden yang mempersepsikan power cukup memenuhi harapan pasien (50,7\%) merasa sangat puas akan pelayanan Poli Umum RSI Jemursari Surabaya. Dan apabila dianalisis secara Pareto 80/20 dapat dikatakan belum efektif dikarenakan power yang cukup memenuhi harapan pasien hanya dapat menjadikan pasien sangat puas sebesar 50,7\% (dibawah 80\%). Power adalah upaya yang dilakukan dalam rangka memanfaatkan peluang yang timbul dari adanya peraturan mengenai usaha yang dilakukan atau bisa juga diartikan sebagai mengenali, membina hubungan dengan pihak yang memiliki pengaruh terhadap 
pasar. Power disini meliputi kekuatan merk atau barang itu sendiri yang tercipta di benak konsumen dan mampu membuat produknya menjadi kuat di pasaran.

Responden yang mempersepsikan bahwa responden yang mengatakan marketing mix 9P sudah cukup optimal $(65,4 \%)$ merasa cukup puas akan pelayanan di Poli Umum RSI Jemursari Surabaya. Hasil analisis secara Pareto 80/20 belum bisa dikatakan efektif dikarenakan marketing mix 9P yang sudah cukup optimal hanya dapat menjadikan pasien cukup puas hanya sebesar 65,4\% (dibawah 80\%). Marketing mix 9P merupakan suatu strategi pemasaran yang menggabungkan beberapa elemen (9 elemen) di dalam marketing mix itu sendiri yang dilakukan secara terpadu. Elemen-elemen di dalam Marketing mix 9P terdiri dari Product, Price, Place, Promotion, People, Process, Physical Evidence, Public Relation, Power yang teridentifikasi berkaitan erat dengan kepuasan pelayanan. Hal ini senada dengan pendapat (Wilson, 2012) bahwa untuk menciptakan kepuasan pelayanan harus dapat mengintegrasikan semua komponen bauran pemasaran dan selalu menjaga upaya bauran pemasaran untuk tetap berjalan dengan baik.

\section{SIMPULAN}

Pada pelaksanaan marketing mix product, price, place, process, public relation, power sebagian besar mempersepsikan cukup memenuhi harapan pasien. People dan physical evidence sebagian besar mempersepsikan sudah sesuai harapan pasien. Hanya separuh responden yang merasa sangat puas terhadap pelayanan rawat jalan RSI Jemursari Surabaya. Pelaksanaan marketing mix 9P sebagian besar namun belum 80\% responden mengatakan sudah optimal. Untuk hasil analisis pareto marketing mix 9P terhadap kepuasan pelayanan adalah Marketing mix product, place, promotion, people, process, physical evidence, public relation, power belum efektif karena pasien yang sangat puas masih dibawah $80 \%$. Marketing Mix price responden yang cukup puas 100\% dan ini bisa dikatakan cukup efektif karena melebihi 80\%. Marketing Mix 9P dikatakan belum efektif karena walaupun sebagian responden mengatakan sudah cukup optimal namun pasien yang cukup puas masih dibawah $80 \%$. 
Satriya Wijaya, Agus Aan Adriansyah : The Effectiveness of 9P Marketing Mix ...

\section{UCAPAN TERIMA KASIH}

Kepada Kemenristek Dikti yang telah memberikan anggaran hibah Penelitian Dosen Pemula sehingga terciptanya artikel penelitian ini. Kepada Universitas Nahdlatul Ulama Surabaya untuk dukungan dan supportnya serta sebagai kampus bernaung tempat saya bekerja. Kepada Stikes Yayasan RS Dr. Soetomo Surabaya yang telah memfasilitasi dan menerbitkan artikel penelitian ini.

\section{DAFTAR PUSTAKA}

Davis, G. B., \& Dasar, K. (2012). Sistem Informasi Manajemen, Bagian I Pengantar. Seri Manajemen, (90-A).

Griffin, J. (2005). Customer loyalty: Menumbuhkan dan mempertahankan kesetiaan pelanggan. Jakarta: Erlangga.

Haughey, D. (2010). Pareto analysis step by step. London: Project Smart.

Kotler, P., Armstrong, G., Ang, S. H., Leong, S. M., Tan, C. T., \& Ho-Ming, O. (2012). Principles of marketing: an Asian perspective. Pearson/Prentice-Hall.

Kotler, P., \& Armstrong, G. M. (2018). Marketing Mix: Selected Chapters From: Principles of Marketing, Philip Kotler and Gary Armstrong. Pearson.

Monroe, K. B. (2011). Some personal reflections on pricing research. Review of Marketing Research, 8, 209-241.

Notoatmodjo, S. (2010). Metododologi Penelitian Kesehatan.

Sukotjo, H., \& Radix, S. A. (2010). Analisa Marketing Mix-7P (Produk, Price, Promotion, Place, Partisipant, Process, dan Physical Evidence) terhadap Keputusan Pembelian Produk Klinik Kecantikan Teta di Surabaya. Jurnal Mitra Ekonomi Dan Manajemen Bisnis, 1(2), 216-228.

Widayati, D. (2012). Pengaruh Kualitas Produk dan Harga Terhadap Keputusan Pembelian Produk Tupperware di Yogyakarta. Jurnal Manajemen, 2(2), 6574.

Wilson, D. D. (2012). A., Zeithaml, VA, Bitner, MJ, \& Gremler, Services marketing: Integrating customer focus across the firm. McGraw Hill.

\begin{tabular}{|l|l|}
\hline Submission & 4 Desember 2019 \\
\hline Review & 12 Desember 2019 \\
\hline Accept & 29 Maret 2020 \\
\hline Publish & 23 April 2020 \\
\hline DOI & $10.29241 / j m k . v \% v i \% i .279$ \\
\hline Sinta Level & 4 (Empat) \\
\hline
\end{tabular}

